$\begin{gathered}\text { EPiC Series in Education Science } \\ \text { Volume 1, 2017, Pages 411-418 }\end{gathered}$
$\begin{gathered}\text { AUBEA 2017: Australasian Universities Build- } \\ \text { ing Education Association Conference 2017 }\end{gathered}$

\title{
A Framework for Property Developers to Survive in a Recession
}

\author{
Zunoon Parambath ${ }^{1 * 1}$ and Nilupa Udawatta ${ }^{1 \dagger}$ \\ Deakin University, Australia \\ zunooncp@gmail.com, nilupa.udawatta@deakin.edu.au
}

\begin{abstract}
Recession is considered as a major threat to the economy as it slows down the economic activities. The property development sector is extremely responsive to these economic conditions. Thus, it is crucial to understand causes, effects and strategies for property developers to survive in a recession without any ill effects. Thus, this research aimed to develop a framework for property developers to identify appropriate survival strategies in a recession. A comprehensive literature review was conducted in this research to achieve the above mentioned aim. The results of this study indicated that recession prompts negative impacts on the property development sector resulting in unemployment, low demand, low production, low revenue, decline in resources and high level of competition. According to the results, the survival strategies were classified into short-term and long-term strategies. The short term strategies include: implementing management tactics; cut down of operating costs; keeping financing lines set up; timely repayment of debts; setting vital new objectives for the future; undertaking shortterm developments; specialisation in favoured market; and renegotiating contracts. The long-term strategies include: retrenchment; restructuring; investment; and ambidextrous strategies. Similarly, attention should be paid to predict any changes in the economic environment that can influence property development activities and it is necessary to carefully evaluate the investment activities to increase sales, profits and market shares of property developers. Preparing for a crisis is doubtlessly the ideal approach as it can facilitate both survival and growth. Thus, the property developers can implement these suggested strategies in their businesses to enhance their practices.
\end{abstract}

Keywords: Effects, Property Development, Recession, Strategies.

* Prepared as a requirement of Masters Degree

$\dagger$ Supervised and edited the student's work

M. Lamb (ed.), AUBEA 2017 (EPiC Series in Education Science, vol. 1), pp. 411-418 


\section{Introduction}

The construction industry is sensitive to economic changes and these changes can affect outputs of the construction industry (Tse \& Ganesan, 1997). The world economy suffered from a major recession in the period of 2007-2009, which had severe impacts on various sectors including property development. This can cause enormous strains on organisations resulting in numerous business failures and closedowns (Grusky, Western, \& Wimer, 2011). The current economic environment in Australia is growing, despite of the fact that there is still a great deal of instability in the economy (RBA, 2015). However, Keen (2016) predicted that Australia is most likely to have a debt crisis in next couple of years. Thus, a recession can directly influence property development by reducing its demand, cash flows and profits (Byrne, 2002). This can place pressure on organisations and they have to set up clear techniques to survive in a recession. The literature acknowledges that property development as a risk prone business due to its procyclical nature. Thus, it is important to understand the field of property development and the threats imposed by recession on it. The organisations that have efficient management plans can survive in a recession (Gulati, Nohria, \& Wohlgezogen, 2010) and effective strategies to survive in a recession can be planned by identifying the pressures and opportunities during a recession. As a result of that, property developers could not only survive but also use recession as an opportunity to progress in their businesses (Bryson, 1996). Thus, the aim of this research is to develop a framework for property developers to identify appropriate survival strategies in recession. A comprehensive literature review was undertaken by reviewing books, research papers, and web sources to study the context of this research.

\section{Literature Review}

\subsection{Property Development and recession}

According to Chitsulo (2013), property development is a process in which the utility of a property or building is improved by developing facilities that meet social, business and infrastructural needs. As developers usually function as investors or traders (Byrne, 2002), the main aim of the property development is to make economic earnings or value addition by the method of development. However, the property development sector is extremely responsive to economic changes and surviving in a recession can be a challenging task for property developers. Iqbal and Vitner (2010) define recession as a substantial downturn in economic activity that can last over few months. As shown in the Figure 1 , the duration between peak and trough is recorded as recession whereas the duration between trough and peak is considered as an expansion. A recession can continue a couple of months or years and it causes substantial decline in the economic activities. Likewise, through expansion phase, the economic activity grows significantly and lasts for some years (Emeriti, 2009). 


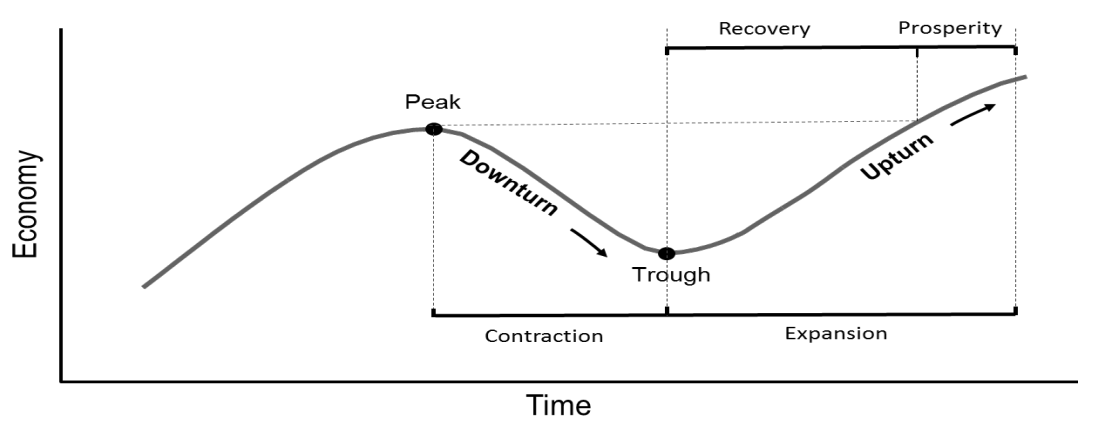

Figure 1: Business Cycle Model

\subsection{Causes and effects of recession}

An increase in inflation coupled with a loss of business and consumer confidence result a reduction of cash supply in an economy is believed to be the root cause of a recession (Grusky et al., 2011). Thus, less quantity of products and services can be purchased using the same amount of money (Allen \& Gale 2007) and there could be a drop in the demand for products and services, which leads to drop in production causing cutbacks and unemployment. Investors would fear that stock prices would fall and spend less leading to a stock market crash (Rhoads \& Gupta, 2010).

The common negative effects of recession include unemployment, low demand, low production, low profits, high competition and fall in share trading (Grusky et al., 2011). Recession also causes significant reduction in resources that are available for companies as clients spend less and creditors lend less and these lead high competition in property development (Pearce \& Michael, 2006). Prices fall due to high competition and lower demand, which in turn results in declining productivity and lower revenue during this period (Domowitz, Hubbard, \& Petersen, 1987). Similarly, high interest rates can limit liquidity or the available funds for investment (Altman, 2009). Thus, reluctance of banks in providing business loans can cause more business failures and closedowns. Thus, recession can result in lower demand, drop in profits and credits, leading to significant impact on accessibility to resources by property developers (Kaplan \& Norton, 2004). However, Bryson (1996) views recession as an opportunity to innovate concepts, technologies and products where industries can evolve. Governments typically respond to recessions by using expansionary macroeconomic approaches like, growing cash supply, improving government spending and reducing taxes (Grusky et al., 2011). Thus, effective management and business strategies should be developed to reduce the negative effects of a recession on property developers.

\subsection{What Measures Can Companies take during Recession?}

The selection of survival strategy depends on company's financial condition and its operating style (Hyland, 2010). According to Banerji et al. (2009), in order to survive in a recession, it is necessary to evaluate the company's commercial environment to determine the suitable strategies for survival. These survival strategies can be divided into short-term and long-term strategies as discussed in the following sections.

\section{Short-term Strategies}

During a recession, organisations generally start with minor cost controls such as reducing expenditure, cutting travel expenses, discretionary costs and communication (Raghavan, 2009). Gupta 
(2009) describes that short-term strategies are executed when managers act quickly to solve difficult situations. These actions include: salary cuts; immediate layoffs; postponing activities; pausing employee development; and preserving money. According to Altman (2009), the following strategies can be used by property developers to survive in a recession.

- Closely monitor stocks to avoid accumulating dead stocks until the desired price is obtained or due to low requirements

- $\quad$ Pay off debts in time to reduce debt exposures

- Negotiate with contractors, clients and landowners

- $\quad$ Reduce costs of advertising

- Search for new markets

- Monitor costs and expenditures

- Undertake short period development projects

Employee management and performance management become the key factors to progress during a recession. The accountability system of the company should be able to provide employees a proper focus and understanding that their workloads (Bidya, 2009). These strategies could include: decisions on employees; new developments/ products; control of capital expenses; and research and development (Banerji et al., 2009).

\section{Long-term Strategies}

Companies need to implement major business strategies to achieve their long-term goals. Arieu (2007) defines business strategy as a long-term plan that is developed to achieve a specific aim or a number of objectives. Typically, firms have to evaluate their strategic position before choosing a business strategy by understanding market pressures, threats and opportunities, assessing their strategic ability and evaluating the enablers and limitations of selected strategy (O'Gorman 2006). The common and most effective business strategies include: retrenchment; restructuring; investment; and ambidextrous.

\section{Retrenchment Strategy}

Retrenchment strategy mainly aims in stabilising the company's financial situation (Kitching, Blackburn, Smallbone, \& Dixon, 2009). The outline of retrenchment involves: downsizing; closure of facilities; consolidating work and departments; decentralization; decrease in employment; reduce expenses in marketing, staff training, research and development; and high level of control (Pearce and Michael, 2006). In a positive perspective, retrenchment strategy enables firms to reassess their portfolios by considering their core values and it provides rationale for expanding productivity by reducing working expenses and divestment of non-core resources. However, cost and resource cutting can be a spontaneous response to poor economic situations, instead of a proactive alteration of the firm as it reduces ability of businesses perform well when economy expands (O'Neill, 1986). There are two divisions of retrenchment strategy such as cost cutting strategy and asset reduction strategy. Cost cutting strategy mainly focuses on the firms' ability to operate efficiently by lowering profits and maintaining a steady cash flow. Cost cutting techniques are expected to provide optimistic results compared to income generation and asset reduction (Lantham, 2009). Asset reduction strategy involves in sale of assets with low income and other unimportant properties (Kaplan and Norton, 2004). However, Hofer (1980) stated that these measures must be carefully and intentionally considered as those could have potential damaging effects on companies. These strategies can give one-time infusion of non-operating cash flow that may moderate income strains brought on by economic uncertainty (Bryson, 1996).

\section{Restructuring strategy}

Restructuring strategy involves in making the company profitable by reorganising the ownership, operational, legal and other structures, or better management of resources to meet its current needs. It also includes financing loans, selling part of the firm to investors, restructuring or decreasing operations and relocating activities (Norley, Marshall, \& Swanson, 2008). The process of restructuring covers 
changes in execution, marketing, finance and services. Production restructuring, cost and performance improvement can be achieved by outsourcing skills and services to specialised firms. Hiring local talents and training them to meet the requirements also become a part of functional restructuring (Gurkov, 2009). Laying off excess staff and training in useful aptitudes can empower an effective functional restructuring if it is combined with a fundamental plan to accommodate most part of the layers of the old structure (Geroski and Gregg, 1994).

\section{Investment Strategy}

This strategy includes spending on diversification and innovation (Rumelt, 2009). This strategy is implemented by organisations who see recession as a chance to invest, innovate and enter new markets to get a competitive advantage. Many prominent companies took this advantage and launched successful businesses during a recession (Norley et al., 2008). Similarly, developers can consider purchasing properties and acquiring smaller companies during a recession. Potential alternatives for new development activities as suggested by Banerji, McArthur, Mainardi and Ammann (2009) are expanding in developing markets, investing in innovation and spending on individuals/talents and acquisitions. It is evident from previous recessions that developers have gained an advantage by developing innovative structures, facilities and advanced business models by expanding into different markets (Norley et al., 2008). Investment strategies need assets, funds, administrative capabilities and technical expertise to implement them (Rumelt, 2009). However, such techniques are unsafe and most organisations are probably going to be occupied with short-term strategies, making it is impossible to consider innovation and development (Steven, 1998).

\section{Ambidextrous strategy}

This strategy is a combination of investment and retrenchment. It is vital for organisations to maintain a balance between exploration and exploitation for long-term success. Exploitation involves with the process of refining and extending the current capabilities, technologies and model whereas exploration includes testing and discovering new alternatives (Raisch \& Birkinshaw, 2008). Ambidextrous companies integrate incremental development with intermittent change or utilisation of available resources to increase their efficiency and exploring different resources with competitive advantage and innovation (He \& Wong, 2009). If firms adopt cost-cutting measures alone, they could be incapable to take benefit when the market situation improves (Raisch, Birkinshaw, Probst, \& Tushman et al., 2009). There are three strategies to manage and achieve organisational ambidexterity such as structural, sequential and contextual. When structural ambidexterity is used in a company exploitation and exploration activities will be divided into separate divisions for each activity to enable differentiation between tasks (Lantham, 2009). Difficulty in integrating different groups and cost become main obstacles in applying this strategy in a development firm (Raisch \& Birkinshaw, 2008). In sequential ambidexterity strategy, exploration and exploitation activities are undertaken in the same unit and same people but at different periods (He \& Wong, 2009). This strategy is suitable for companies/projects with fewer resources since separation of one unit into smaller ones can be costly to undertake and manage (Eriksson, 2012). In contextual ambidexterity strategy, exploration and exploitation is executed in the same unit simultaneously (He \& Wong, 2009). However, the level of ambidexterity depends on the culture of the organisation.

\section{The Proposed Conceptual Framework}

Industrial context, market conditions and the level of government support will influence the process of selecting a suitable strategy for organisations to survive in a recession (Grusky et al., 2011; O'Gorman, 2006). The company's resources and capabilities can be utilised to achieve better operational efficiency and the dynamic capability can be used to explore new markets and opportunities. These strategies can be executed using a range of income generating and efficiency-improving 
measures. The performance outcomes of these strategies can be measured through indicators like sales, profit and market performance as shown in the following diagram.
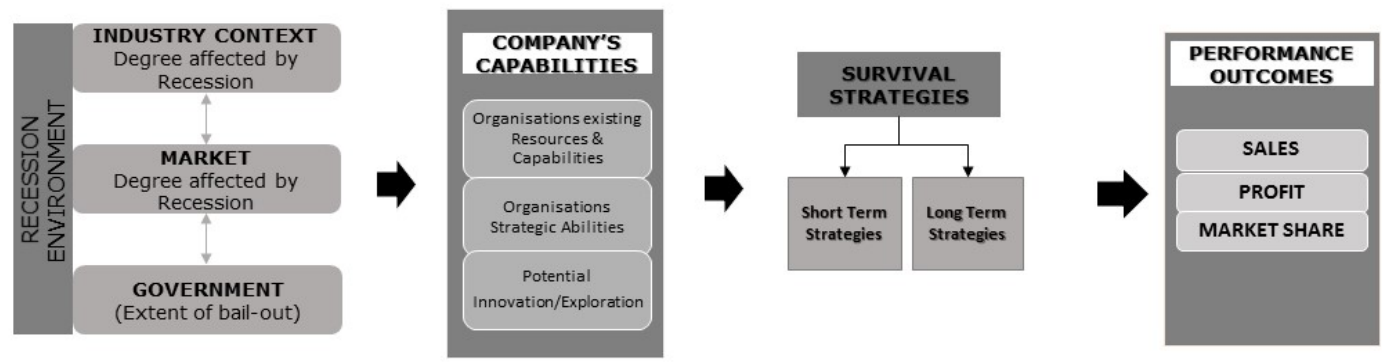

Figure 2: Systematic Framework

The framework related to the short-term and long-term strategies is presented in Figure 3. This framework summarises the key strategies and measures identified and discussed in this paper. The advantages and disadvantages in implementing each strategy is also included in the framework. This will help developers to select an appropriate strategy depending on their circumstances

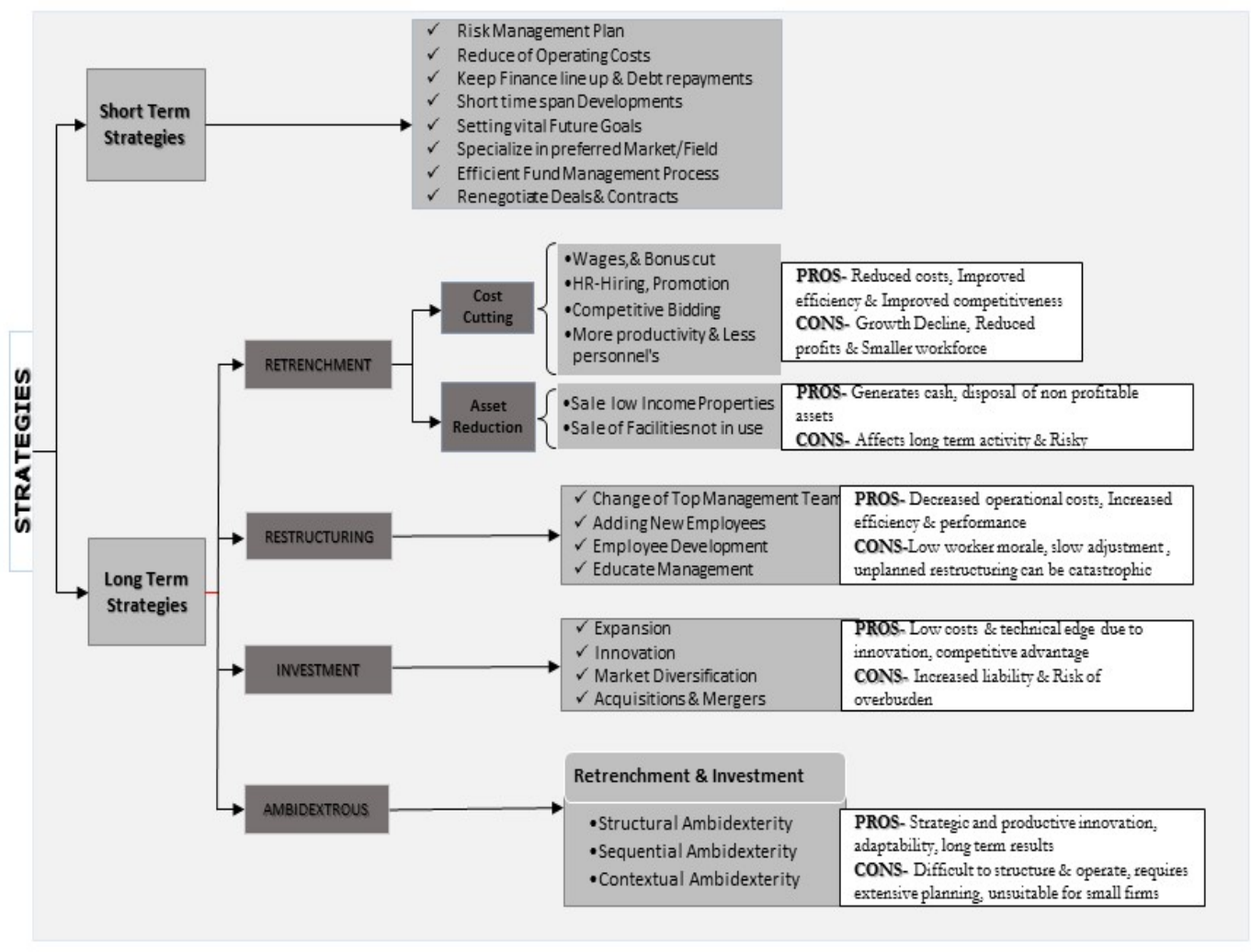

Figure 3: Framework to implement survival strategies in a recession 


\section{Conclusions}

Recession has several negative effects on the economy such as high interest rates, credit reduction, unemployment, low demands, low production and low profits, drop in resources, high competition and fall in share trading. However, the effective survival strategies that can be implemented in recession are more likely to be context specific and can be varied on industrial and geographical conditions. Thus, the aim of the research was to develop a framework that can be used by property developers to find out the suitable strategy to survive in a recession. The initial strategies embraced at the outbreak of recession are reduction in working expenses and overheads. After that it is necessary to use administration techniques to identify the most suitable strategies for survival. However, there is no single technique that assures survival or success of the business during a recession. The evidence available offers no consensus in the matter of whether retrenchment, restructuring, investment or ambidextrous strategies are more likely help property developers to survival in a recession. According to the literature, the ambidextrous strategy combines judicious cost cutting measures with equally carefully chosen investment activities to increase sales, margin and market share. However, decline in available resources, market and other factors are likely to prevent their adaptation in firms. Thus, it becomes extremely important for businesses to analyse the key factors, which influence their performance in a recession. Similarly, in order to successfully adapt these strategies it is necessary to understand the internal and external factors that allow or limit their adaptation to the crisis. Thus, it is recommended for organisations to monitor their business cycles closely to adapt different business strategies during a recession. However, it is necessary to conduct further research studies to understand the relationship between these survival strategies and their effectiveness in a recession.

\section{References}

Allen, F., \& Gale, D. (2007). Understanding Financial Crises, Oxford University Press, Oxford.

Altman, W. (2009). 'Managing in a downturn [global recession]', Engineering \& Technology, vol. 4 (2), pp. 76-79.

Arieu, O. (2007). Business Strategy: The Art, Science, and Craft of Decision-Making, Retrieved from https://learn.saylor.org/mod/page/view.php?id=7251

Banerji, S., McArthur, N., Mainardi, C., \& Ammann, C. (2009). Recession response: why companies are making the wrong moves, Booz \& Company.

Bidya, D. (2009). A study on performance management through recession metrics during downturn. Advances in Management, 2(10), 27-30.

Bryson, J.R. (1996). Small Business Service Firms in the 1990s Recession in the United Kingdom: Implications for Local economic Development. Local Economy, 11(3), 221- 236.

Byrne, P. (2002). Risk, uncertainty and decision-making in property, Routledge: London.

Chitsulo, H. (2013). Introduction to Property Development. Entrepreneur Empowerment Property Fund, 3.

Domowitz, I., Hubbard, R. G., \& Petersen, B. C. (1987). Oligopoly super games: Some empirical evidence on prices and margins. Journal of Industrial Economics, 35(4), 379-381.

Emeriti, D. (2009). NBER Board of Directors: NBER Macroeconomics Annual, 24(1).

Eriksson, P. (2012). Exploration and exploitation in project-based organizations: Development and diffusion of knowledge at different organizational levels in construction companies. International Journal of Project Management, 31(3), 333-341.

Geroski, P., \& Gregg, P. (1994). Corporate restructuring in the UK during the recession. Business Strategy Review, 5(2), 1-19. 
Grusky, D. B., Western, B., \& Wimer, C. (2011). The Great Recession, Russell Sage Foundation: New York.

Gulati, R., Nohria, N., \& Wohlgezogen, F. (2010). Roaring Out Of Recession. Harvard Business Review, 88(3), 62-69.

Gupta, U. (2009). Recession: causes, problems and effects, Abhishek Publications: New Delhi.

Gurkov, I. (2009). The strategy process in Russian: Non-strategic companies: coping with recession. Post-communist Economics, 21(4), pp.439-451.

He, Z. L., \& Wong, P. K. (2004). Exploration vs. exploitation: An empirical test of the ambidexterity hypothesis. Organisation Science, 15(4), 481- 494.

Hofer, C. W. (1980). Turnaround Strategies. Journal of Business Strategy, 1 (1), 19-31.

Hyland, P. (2010). Organisational responses to financial crisis: An exploration study of various strategies, SIROTA Survey Intelligence.

Iqbal, A., \& Vitner, M. (2010). The deeper the recession, the stronger the recovery: is it really that simple?. Business Economics, 46(1), 22-31.

Kaplan. R.S., \& Norton, D.P. (2004). Strategy maps: Converting intangible assets into tangible outcomes, Harvard Business Press.

Keen, S. (2016). The seven countries most vulnerable to a debt crisis. Forbes Welcome, Retrieved from https://www.forbes.com/sites/stevekeen/2016/03/27/the-seven-countries-mostvulnerable-to-a-debt-crisis/\#71ed5d6dce5a.

Kitching. J., Blackburn, R., Smallbone, D., \& Dixon, S. (2009). Business Strategies and Performance during difficult economic conditions. Retrieved from http://eprints.kingston.ac.uk/5852/1/Kitching-J-5852.pdf

Norley, L., Marshall, P., \& Swanson, J. (2008). A Practitioner's guide to corporate restructuring. City \& Financial Publishing.

O'Gorman, C. (2006). Strategy and the small business. In S. Carter and D. Jones- Evans (eds), Enterprise and Small Business, Financial Times/Prentice Hall: Harlow.

O'Neill, H. M. (1986). Turnaround and recovery: what strategy do you need?. Long Range Planning, 19(1), 80-88.

Pearce, J.A., \& Michael. S.C. (2006). Strategies to prevent economic recessions from causing business failure. Business Horizons, 49 (3), 201-209.

Raghavan, A. (2009). The economic downturn: coping strategies and the way forward. Vikalpa, 34(3), 67-72.

Raisch, S., \& Birkinshaw, J. (2008). Organisational ambidexterity: antecedents, outcomes and moderators. Journal of Management, 34(3), 375-409.

Raisch, S., Birkinshaw, J., Probst, G., \& Tushman, M. (2009). Organizational Ambidexterity: Balancing Exploitation and Exploration for Sustained Performance. Organization Science, 20(4), 685-695.

RBA, (2015). Statement on monetary policy - February 2016 3. Domestic economic conditions.

Rhoads, C., \& Gupta, K. (2010). An empirical look at past recessions: strategy lessons learned for the business community proceedings summary. Northeast business \& economics association, 559-564.

Rumelt, R.P. (2009). Strategy in a 'Structural Break. McKinsey Quarterly, 1, 35-42.

Steven,C.M. (1998). Strategies among small manufacturing firms during the recession. Journal of Small Business Management, 36 (3), 35-45.

Tse, R., \& Ganesan, S. (1997). Causal relationship between construction flows and GDP: evidence from Hong Kong. Construction Management and Economics, 15(4), 371-376. 